\title{
ANALYSIS OF THE NUCLEOTIDE SEQUENCE OF THE COAT PROTEIN AND 3'- UNTRANSLATED REGION OF TWO BRAZILIAN Potato virus Y ISOLATES
}

\author{
ALICE K. INOUE-NAGATA ${ }^{1 *}$, M. ESTHER N. FONSECA ${ }^{1}$, TATIANA O.T.A. LOBO ${ }^{1}$, \\ ANTÔNIO C. DE ÁVILA ${ }^{2} \&$ DAMARES C. MONTE ${ }^{1}$ \\ 'Embrapa Recursos Genéticos e Biotecnologia, Cx. Postal 02372, CEP 70770-900, Brasília, DF, fax: (61) 340-3624, e-mail: \\ alicenag@cnph.embrapa.br; ²Embrapa Hortaliças, Cx. Postal 0218, CEP 70359-970, Brasília, DF
}

(Accepted for publication on 05/12/2000)

Corresponding author: Alice Kazuko Inoue-Nagata

INOUE-NAGATA, A.K., FONSECA, M.E.N., LOBO, T.O.T.A., DE ÁVILA, A.C. \& MONTE, D.C. Analysis of the nucleotide sequence of the coat protein and 3'-untranslated region of two Brazilian Potato virus $Y$ isolates. Fitopatologia Brasileira 26:45-52. 2001.

\begin{abstract}
Two Brazilian Potato virus $Y$ (PVY) isolates were biologically characterized as necrotic (PVY-NBR) and common (PVY-OBR) based upon symptoms on test plants. Additional characterization was performed by sequencing a cDNA corresponding to the 3 ' terminal region of the viral genome. The sequence consisted of 195 nucleotides (nt) coding part of the nuclear inclusion body b (NIb) gene, 804 nt of the coat protein $(\mathrm{CP})$ gene, and $328 \mathrm{nt}$ (PVY-OBR) or $326 \mathrm{nt}$ (PVY-NBR) of the 3'-untranslated region (UTR). Translation of the sequence resulted in one single open reading frame with part of the $\mathrm{NIb}$ and a $\mathrm{CP}$ of 267 amino

acids. The two isolates shared $95.1 \%$ similarity in the CP amino acid sequence. The $\mathrm{CP}$ and the 3'-UTR sequence of the Brazilian isolates were compared to those of other PVY isolates previously reported and unrooted phylogenetic trees were constructed. The trees revealed a separation of two distinct clusters, one comprising most of the common strains and the other comprising the necrotic strains. PVY-OBR was clustered in the common group and PVY-NBR in the necrotic one.

Key words: PVY, Potyvirus, phylogenetic analysis, taxonomy, coat protein.

\section{RESUMO}

Análise da seqüência de nucleotídeos da capa proteica e da região 3 ' não codificadora de dois isolados brasileiros de Potato virus $Y$

Dois isolados do vírus Y da batata (Potato virus Y, PVY) foram caracterizados biologicamente como pertencentes às estirpes necrótica (PVY-NBR ) e comum (PVY-OBR) com base nos sintomas induzidos em plantas-teste. Caracterização adicional foi realizada com a determinação da sequiência de nucleotídeos do cDNA correspondente à extremidade 3 ' do genoma viral. A seqüência obtida continha 195 nucleotídeos (nt) que codificam uma parte do gene da inclusão nuclear $b$ (NIb), 804 nt da capa proteíca (CP) e 328 nt em PVY-OBR e 326 nt em PVY-NBR da região 3' não traduzida (UTR). A análise da seqüência mostrou ser composta por uma única

fase aberta de leitura contendo parte do NIb e a CP consistindo de 267 aminoácidos. Os dois isolados apresentaram uma similaridade de $95,1 \%$ na sequiência de aminoácidos da CP. A CP e a seqüência 3'-UTR dos isolados brasileiros foram comparados com as sequiências de outros isolados de PVY previamente relatados e árvores filogenéticas foram construídas. As árvores mostraram a delimitação de dois grupos distintos, um contendo a maioria das estirpes comuns e o outro com as estirpes necróticas. PVY-OBR foi agrupado no grupo comum e PVY-NBR no necrótico.
\end{abstract}

\section{INTRODUCTION}

Potato virus $Y(\mathrm{PVY})$ is the type species of the genus Potyvirus from the family Potyviridae. This virus causes serious losses in many important crops worldwide, especially in solanaceous plants such as potato (Solanum tuberosum L.), pepper (Capsicum annuum L.), and tobacco (Nicotiana

\footnotetext{
* Present address: Embrapa Hortaliças, Caixa Postal 0218, CEP 70359970, Brasília, DF
}

tabacum L.). Three PVY strains are recognized by their distinct host responses: the common strain $\left(\mathrm{PVY}^{\circ}\right)$, which causes mosaic and mottling symptoms in $N$. tabacum plants; the tobacco veinal necrosis strain $\left(\mathrm{PVY}^{\mathrm{N}}\right)$, causing necrotic symptoms in N. tabacum; and the stipple streak strain $\left(\mathrm{PVY}^{\mathrm{C}}\right)$, characterized by the hypersensitive reaction caused in many potato cultivars (De Bokx \& Huttinga, 1981). Recently, a new PVY isolate causing the potato tuber necrotic ring disease (PTNRD) was reported as caused by a new variant of PVY, $\mathrm{PVY}^{\mathrm{NTN}}$ (Beczner et al., 1984; Le Romancer et al., 1994). 
Under Brazilian conditions, the occurrence of $\mathrm{PVY} \mathrm{Y}^{\mathrm{O}}$ and $\mathrm{PVY}^{\mathrm{N}}$ strains (based upon reaction on potato and tobacco plants) are widely reported (Silberschmidt et al., 1954; Montenegro et al., 1968; Alexandre \& Barradas, 1982).

The nucleotide or amino acid sequence of the viral genome has been especially important to classify the species and strains of the Potyvirus genus (Van der Vlugt et al., 1993). The availability of this information is also a prerequisite for the success of new control measures, e.g. methods based on transgenic resistant plants expressing viral genes (Tennant et al., 1994). Many of the transgenic approaches are based upon specific interactions between the transgene and the predominant virus in a given environment, which underlines the need for sequencing local virus strains.

Here, two Brazilian PVY isolates from potato were studied and the nucleotide sequence of part of the inclusion body b (NIb) gene, the coat protein (CP) gene and the 3'untranslated region (UTR) were determined. The taxonomical position of these Brazilian PVY isolates are discussed in this report.

\section{MATERIALS AND METHODS}

\section{PVY isolates}

Thy PVY isolates, PVY-OBR and PVY-NBR, used in this study were originally collected from potato in the Federal District region more than 15 years ago. Since their collection, they were maintained in the greenhouse of Embrapa Vegetables in $N$. tabacum TNN plants by mechanical inoculation using $0.01 \mathrm{M}$ potassium phosphate buffer, $\mathrm{pH} 7.0$, with $0.01 \mathrm{M}$ sodium sulfite as inoculation buffer.

\section{Host response}

The PVY isolates were mechanically inoculated to 14 test plants (Table 1). Inoculated plants were incubated under greenhouse conditions for symptom development up to 30 days after inoculation.

\section{cDNA Cloning and sequencing of the viral 3 ' terminal region}

Total RNA was extracted from infected $N$. tabacum TNN plants using Tri Reagent RNA extraction solution (Sigma). The total RNA was then used for cDNA synthesis primed with oligo d(T) (T-primed first-strand kit, Pharmacia). PCR was performed using Taq polymerase (GIBCO-BRL) and the primers PY1 and PY2 (Table 2). The amplified DNA fragments amplified of ca. 1.330 bases were cloned in pGEM-T vector (Promega) following recommendation of the manufacturer. The nucleotide sequence was determined by automated sequencing using vector (T7 and SP6) and internal (PY3, PY4, and PY5) primers (Table 2).

\section{Nucleotide sequence analysis}

The nucleotide sequences were compiled and analyzed using programs of the University of Wisconsin Genetics Computer group (GCG, Madison, USA) (Devereux et al.,
TABLE 1 - Reactions of test plants inoculated with the Potato virus $Y$ isolates $\mathrm{OBR}$ and NBR

\begin{tabular}{|c|c|c|}
\hline Test plant & PVY-OBR & PVY-NBR \\
\hline Capsicum annuum L. 'Ikeda' & - & - \\
\hline C. chinense Jacq. (PI 159236) & - & - \\
\hline $\begin{array}{l}\text { Chenopodium amaranticolor } \\
\text { Coste \& Reyn. }\end{array}$ & CLL, NLL & - \\
\hline C. quinoa Willd. & CLL, NLL & - \\
\hline Datura stramonium L. & - & - \\
\hline Gomphrena globosa L. & - & - \\
\hline $\begin{array}{l}\text { Lycopersicon esculentum Mill. } \\
\text { 'Rutgers' }\end{array}$ & $\mathrm{VC}, \mathrm{mMT}$ & mMT \\
\hline $\begin{array}{l}\text { Nicandra physaloides (L.) } \\
\text { Gaertn. }\end{array}$ & MT, VC & MT, VC \\
\hline Nicotiana benthamiana Domin. & VC, M, LD & VC, M, LD \\
\hline N. rustica $\mathrm{L}$. & MT & MT, M \\
\hline N. tabacum L. 'TNN' & VC, MT, YS & $\mathrm{VC}, \mathrm{VN}, \mathrm{NS}$ \\
\hline Physalis floridana Rydn. & $\mathrm{mM}, \mathrm{M}, \mathrm{YS}, \mathrm{DL}$ & MT \\
\hline Solanum tuberosum L. 'Achat' & $\mathrm{NS}, \mathrm{VN}$ & $\mathrm{mNS}, \mathrm{VC}$ \\
\hline S. tuberosum 'Bintje' & M & $\mathrm{mMT}$ \\
\hline
\end{tabular}

CLL: chlorotic local lesion; NLL: necrotic local lesion; VC: vein clearing; MT: mottling; M: mosaic; LD: leaf distortion; YS: yellow spot; DL: leaf dropping; NS: necrotic spot; VN: veinal necrosis; m: mild; -: no symptom.

TABLE 2 - Primers used for nucleotide sequence determination

\begin{tabular}{clc}
\hline \hline Primer $^{\mathbf{a}}$ & \multicolumn{1}{c}{${\text { Sequence 5' } \mathbf{\rightarrow} \mathbf{3}^{\mathbf{p}}}^{\mathbf{b}}$} & Position $^{\mathbf{c}}$ \\
\hline PY1 & GGGGGATCCAAATCAGGAGATTC & $8362-8377$ \\
PY2 & CCCGGATCCGTCTCCTGATTGAAG & $9704-9691$ \\
PY3 & CTTAGGCAAATCATGGC & $9038-9054$ \\
PY4 & AAACCATATCGTGGCAT & $9129-9113$ \\
PY5 & CACAGTTTGATACGTGG & $8835-8851$ \\
\hline
\end{tabular}

a The primers were designed according to the sequence of X12456

${ }^{\mathrm{b}}$ Restriction enzyme site (Bam $\mathrm{H} \mathrm{I}$ ) is underlined

${ }^{c}$ Position of the primer according to X12456

1984). PVY sequences were fetched from the GenBank and referred to as the locus name (Table 3), except for PVYNNL (Van der Vlugt et al., 1989), PVYOH (Ohshima et al., 1991) and PVYTH (Hataya et al., 1990). The sequences were aligned and Clustal W (http://www2.ebi.ac.uk/clustalw) was used for phylogenetic tree construction, which was viewed by the program Treeview (http://taxonomy.zoology.gla.ac.uk/rod/ treeview).

\section{RESULTS}

\section{Host response to PVY inoculation}

PVY-OBR and PVY-NBR were originally isolated from potato fields in Brazil and maintained in N. tabacum plants. When inoculated into test plants, they showed typical symptoms of the common and necrotic strains, respectively (Table 1). Datura stramonium and pepper plants were not infected with either isolates and only PVY-OBR caused local lesions in C. amaranticolor and C. quinoa. Nicotiana 
Analysis of the nucleotide sequence of the coat protein...

TABLE 3 - PVY sequences used for nucleotide sequence comparison

\begin{tabular}{|c|c|c|}
\hline $\begin{array}{l}\text { Access } \\
\text { number }\end{array}$ & Locus name & Isolate \\
\hline AF255659 & - & PVY-OBR \\
\hline AF225660 & - & PVY-NBR \\
\hline AJ223592 & pvy 223592 & N 854, necrotic \\
\hline AJ223593 & pvy 223593 & 0768, common \\
\hline AJ223594 & pvy 223594 & 0803, common, Switzerland \\
\hline AJ223595 & pvy 223595 & 0854, common, Switzerland \\
\hline D12539 & pvyocrna & Common, Japan \\
\hline D12570 & pvycp & PVY-T, necrotic, Japan \\
\hline E03317 & pvye 03317 & PVY-T \\
\hline M22470 & pvycpa & New Zealand N-PVY \\
\hline M81435 & pvypolypr & PVY \\
\hline M95491 & pvypolyp & NTN, Hungary \\
\hline S74810 & pvys 74810 & PVY-36, common, Japan \\
\hline S74813 & pvys 74813 & PVY-T13, necrotic, Japan \\
\hline X12456 & pvynxx & Necrotic, France \\
\hline X14136 & pvycoat & Strain Y, common, Argentina \\
\hline X54058 & pvypocp3 & China \\
\hline X54636 & pvycapsi & Necrotic, Russian YN \\
\hline X68221 & pvycapa & NC 178, strain Chilean, from tobacco \\
\hline X68222 & pvycapb & NC 179 , strain Potato US, from tobacco \\
\hline X68223 & pvycapc & NC 189 , strain Europe-H, from tobacco \\
\hline X68224 & pvycapd & NC 78, strain NsNr, from tobacco, USA \\
\hline X68225 & pvycape & NC 138 , strain MsNr, from tobacco, USA \\
\hline X68226 & pvycapf & PVY-O, from tobacco \\
\hline X79305 & pvygcp & NTN \\
\hline X92078 & pvycpgene & Substrain LB \\
\hline X97895 & pvygen & 605, necrotic, Switzerland \\
\hline U09508 & pvyu09508 & N27-92, necrotic, North America \\
\hline U09509 & pvyu09509 & P07, common \\
\hline U10378 & pvyu 10378 & Nnp, from Capsicum annuum \\
\hline $\mathrm{U} 25672$ & pvyu 25672 & China \\
\hline U91747 & pvyu91747 & N27, necrotic, North America \\
\hline Z70237 & pvycpnysa & PVY-N-Nysa, necrotic \\
\hline Z70238 & pvycpwilg & PVYN-Wilga, necrotic \\
\hline$*$ & pvynnl & Necrotic, the Netherlands \\
\hline$*$ & pvyoh & Common, Japan \\
\hline$*$ & pvyth & Necrotic, Japan \\
\hline
\end{tabular}

tabacum TNN showed distinct symptoms. PVY-NBR caused necrotic spots and veinal necrosis, while PVY-OBR caused vein clearing, mottling, and pearl spots. Physalis floridana infected with PVY-OBR showed more severe symptoms than when inoculated with PVY-NBR. PVY-OBR appeared to be more severe in $S$. tuberosum, with systemic necrosis in $\mathrm{cv}$. Achat and mosaic in cv. Bintje. The infection of the test plants was confirmed by DAS-ELISA using a polyclonal antibody (Laboratory of Virology, Embrapa Vegetables) against PVY .

\section{Nucleotide sequence analysis of the 3'end of the PVY genome}

PCR amplification was directed to the conserved region in the nuclear inclusion body $\mathrm{b}(\mathrm{NIb})$ gene approximately 200 bases upstream of the CP gene, and to the last 15 bases of the 3'-UTR, which were completely conserved among all the PVY sequences analyzed. Amplified PCR products were cloned and the sequence of approximately 1.330 nucleotides was determined for both strains using two clones from different PCR amplifications. The comparison of the nucleotide sequence of both isolates, revealed $87.6 \%$ of identity to each other including the NIb, CP and the 3'-UTR (Figure 1). The amplified region of the NIb gene and the $\mathrm{CP}$ gene of both isolates were of the same size (nucleotides 1 to 195 for NIb and 196 to 999 for CP). However, the PVY-OBR 3'-UTR (nucleotides 1000 to 1327) was two nucleotides longer than of PVY-NBR (nucleotides 1000 to 1325). The PVYOBR and PVY-NBR nucleotide sequence were deposited in the GenBank under the accession numbers AF255659 and AF255660, respectively.

Translation of the CP gene resulted in 267 amino acids for both isolates sharing $95.1 \%$ similarity. The amino acid sequences of 35 different PVY isolates were aligned and compared to the Brazilian isolates (data not shown). Most of the heterogeneity was found in the amino terminal region. The similarity between PVY-OBR and the other isolates varied from 94.4 to $99.2 \%$. The highest similarity was found with PVY223594 (isolate 0803) and PVY223595 (isolate 0854), both common strains from Switzerland. PVY-NBR showed amino acid similarity from 93.3 to $99.7 \%$ when compared to other isolates. The highest degree of similarity with PVY-NBR was found with PVYCPNYSA (a necrotic isolate from Poland) and PVYU91747 (a necrotic isolate from North America).

A phylogenetic tree was constructed based on the alignment and displayed as an unrooted tree (Figure 2). PVYOBR was clearly clustered with other common isolates, with the exception of two necrotic isolates (PVYNXX and PVYCPWILG). PVY-NBR was clustered with typical necrotic isolates and the two PVY ${ }^{\mathrm{NTN}}$ isolates (PVYGCP and PVYPOLYP). A potato isolate from Russia (PVYCAPSI) was isolated in a separate branch close to the PVYN cluster, as well as the common isolate from Argentina (PVYCOAT) and a tobacco isolate from Chile (PVYCAPA), both closer to the PVYO cluster. Pepper and tobacco isolates formed a distinct branch including two tobacco isolates from the USA (PVYCAPD and PVYCAPE) and the causal agent of pepper veinal necrosis (PVYU10378).

The 3'-UTR nucleotide sequence of the Brazilian isolates was aligned with 18 available PVY sequences and used for construction of an unrooted phylogenetic tree (Figure 3 ). The consensus sequence found throughout the alignment (data not shown) formed two well defined groups, which were visualized in the phylogenetic tree (Figure 3). The first group comprised all $\mathrm{PVY}^{\mathrm{O}}$-like isolates, except for PVYNXX, the necrotic strain from France (Robaglia et al., 1989), and included PVY ${ }^{\mathrm{NTN}}$ (PVYPOLYP), PVY from pepper (PVYU10378), a PVYN from Poland (PVYCPWILG), an unclassified PVY (PVYPOLYPR) and the PVY ${ }^{\mathrm{N}}$ from Russia (PVYCAPSI). The second group comprised the PVYN isolates and PVYNXX. The sequence of PVYNXX showed high identity with the PVYO group in the first 90 nucleotides and with PVYN for the remaining sequence (data not shown). PVY-OBR showed 98.2 to $99.4 \%$ identity within the PVYO group. The highest values were found with PVYPOLYP, 
A.K.Inoue-Nagata et al.

\begin{tabular}{|c|c|c|c|}
\hline PVY-OBR & 1 & TACTCATGGTTATTGCAACAGCAACCTTTTGCAACAATAGCGCAGGAAGG & 50 \\
\hline PVY-NBR & 1 & 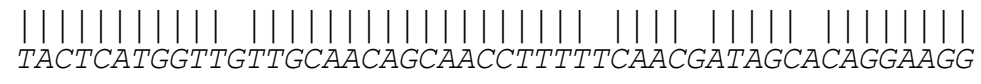 & 50 \\
\hline PVY-OBR & 51 & GAAGGCTCCTTATATAGCAAGCATGGCATTAAGGAAACTGTATATGGATA & 100 \\
\hline PVY-NBR & 51 & AAAAGCTCCATACATAGCGAGCATGGCATTGAAGAAGCTGTACATGAATA & 100 \\
\hline PVY-OBR & 101 & GGACTGTGGATGAGGAAGAGCTAAGAGCCTTCACTGAAATGATGGTCGCA & 150 \\
\hline PVY-NBR & 101 & GGACAGTAGATGAGGAGGAACTGAAGGCTTTCACTGAAATGATGGTTGCC & 150 \\
\hline PVY-OBR & 151 & TTAGACGATGAGTTTGAGTTTGACTCTTATGAAGTACACCATCAAGCAAA & 200 \\
\hline PVY-NBR & 151 & TTGGATGATGAATTTGAGTGCGATACTTATGAAGTGCACCATCAAGGAAA & 200 \\
\hline PVY-OBR & 201 & ГGACACAATTGATGCAGGAGGAAGCAACAAGAGAGATGCAAAACCAG & 250 \\
\hline PVY-NBR & 201 & $\begin{array}{l}\prod_{\text {TGACACAATCGATACAGGAGGAAGCACTAAGAAGGATGCAAAACAAGAGC }} \\
\text { ThA }\end{array}$ & 250 \\
\hline PVY-OBR & 251 & & 300 \\
\hline PVY-NBR & 251 & AAGGTAGCATTCAACCAAAACTCAACAAGGAAAAGGAAAAGGACGTGAAT & 300 \\
\hline PVY-OBR & 301 & & 350 \\
\hline PVY-NBR & 301 & GTTGGAACATCTGGAACTCATACTGTGCCACGAATTAAAGCTATCACGTC & 350 \\
\hline PVY-OBR & 351 & & 400 \\
\hline PVY-NBR & 351 & CAAAATGAGAATGCCCAAGAGTAAAGGTGCAACTGTACTAAATTTGGAAC & 400 \\
\hline PVY-OBR & 401 & ATTTGCTTGAGTATGCTCCACAACAAATTGATATTTCAAATACTCGGGCA & 450 \\
\hline $\mathrm{PVY}-\mathrm{NBR}$ & 401 & ACTTACTCGAGTATGCTCCACAGCAAATTGACATCTCAAATACTCGAGCA & 450 \\
\hline PVY-OBR & 451 & & 500 \\
\hline PVY-NBR & 451 & GTACAACTTGCATACGA & 500 \\
\hline PVY-OBR & 501 & GAAACTGAGATGCCAACTGTGATGAATGGGCTTATGGTTTC & 550 \\
\hline PVY-NBR & 501 & CATAGGAGAAACTGAAATGCCAACTGTGATGAATGGGCTTATGGTTTGGT & 550 \\
\hline PVY-OBR & 551 & GGGAGTTGGGTTATGATG & 600 \\
\hline PVY-NBR & 551 & GCATTGAAAATGGAACCTCGCCAAACATCAACGGAGTTTGGGTTATGATG & 600 \\
\hline PVY-OBR & 601 & ชา & 650 \\
\hline PVY-NBR & 601 & CAAGTCGAATACCCACTGAAACCAATCGTTGAGAATGC & 650 \\
\hline PVY-OBR & 651 & 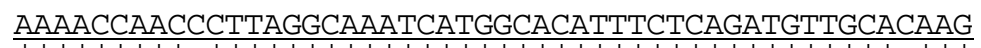 & 700 \\
\hline PVY-NBR & 651 & AAAACCAACACTTAGGCAAATCATGGCACATTTCTCAGATGTTGCAGAAG & 700 \\
\hline PVY-OBR & 701 & AAAGGAACCATATATGCCACGATATGGT & 750 \\
\hline PVY-NBR & 701 & CGTATATAGAAATGCGCAACAAAAAGGAACCATATATGCCACGATATGGT & 750 \\
\hline PVY-OBR & 751 & И И & 800 \\
\hline PVY-NBR & 751 & TTAGTTCGTAATCTGCGCGATGGAAGTTTGGCTCGCTATGCTTTTGACTT & 800 \\
\hline PVY-OBR & 801 & TTATGAGGTCACATCACGAACACCAGTGAGGGCTAGGGAAGCGCACAT & 850 \\
\hline VY- & 801 & TTATGAAGTTACATCACGGACACCAGTGAGGGCTAGAGAGGCACACA & 0 \\
\hline
\end{tabular}




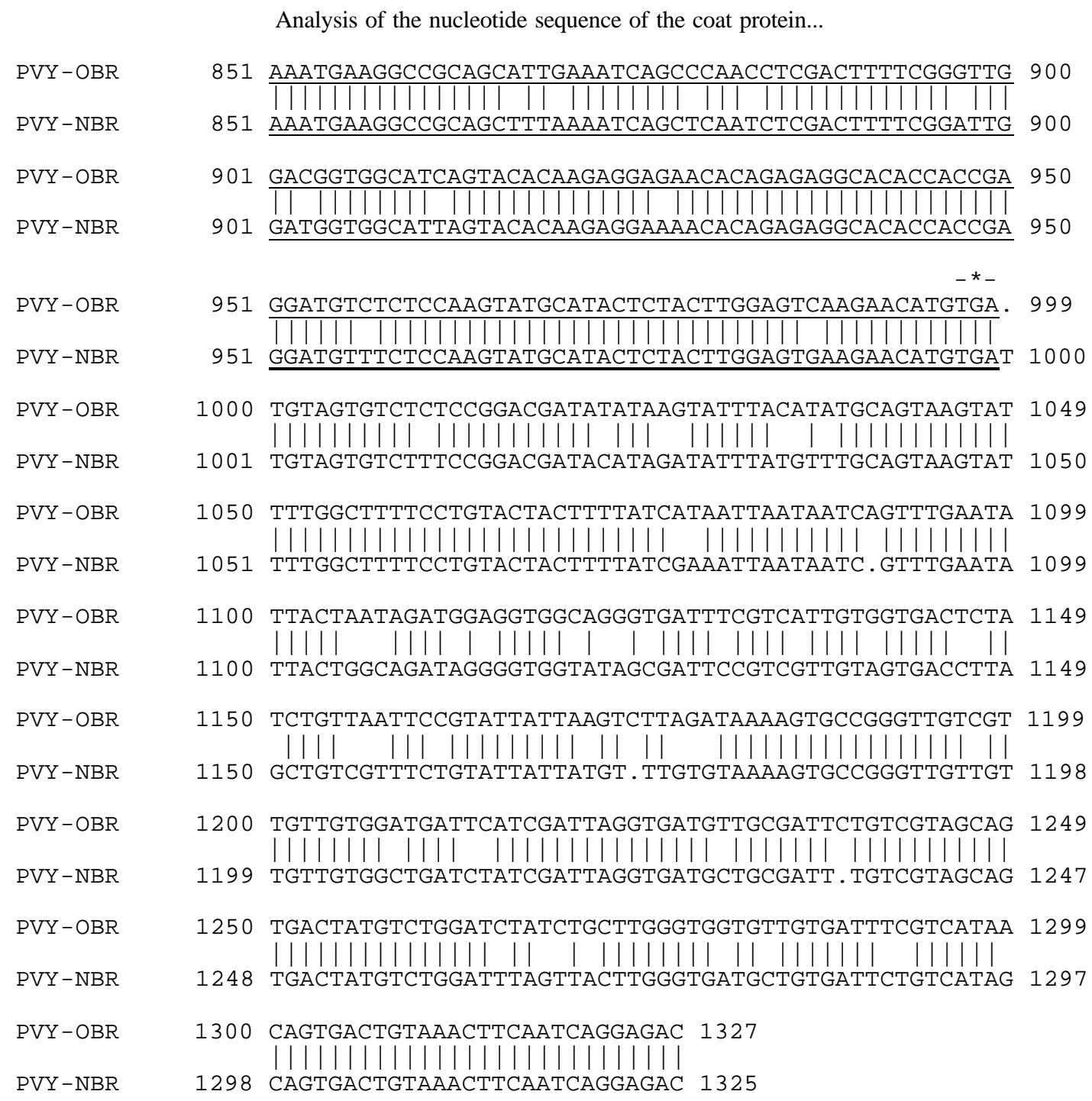

FIG. 1 - Nucleotide sequence comparison of the 3' genome terminal region of PVY-OBR and PVY-NBR cDNAs. Identical nucleotides are linked by vertical bars. Dots were added to the nucleotide sequence to optimize the alignment. The partial sequence of the nuclear inclusion $b$ gene is shown in italics. The coat protein gene is underlined. The stop codon (*) of the polyprotein is shown at position 997-999.

PVYU10378, and PVYCPWILG. The identity ranged from 85.6 to $86.5 \%$ with the PVYN group and was $89.0 \%$ with PVYNXX. The identity of PVY-NBR within the PVYN group ranged from 97.3 to $98.8 \%$ and was $94.4 \%$ with PVYNXX. The highest values were found with the necrotic isolates from Switzerland (PVYGEN) and New Zealand (PVYCPA). The identity ranged from 85.2 to $86.5 \%$ with the $\mathrm{PVY}^{\mathrm{O}}$ group. The two groups showed a high degree of homogeneity within the group and the variability between the two groups was found in stretches of one to three nucleotides scattered throughout the sequence (data not shown).

\section{DISCUSSION}

The host range and nucleotide sequence of the Brazilian PVY-OBR and PVY-NBR isolates confirmed their inclusion in the $\mathrm{PVY}^{\mathrm{O}}$ and $\mathrm{PVY}^{\mathrm{N}}$ group, respectively. A comparison of the amino acid sequence of the CP with other PVY isolates showed that PVY-OBR was closely related to European isolates than the PVYO from Angentina (BravoAlmonacid \& Mentaberry, 1989). Regarding the 3'-UTR, PVY-OBR was closer to necrotic or pepper isolates from Central Europe. PVY-NBR, on the other hand, showed a higher correlation with the necrotic isolates from North America by $\mathrm{CP}$ comparison and with the necrotic isolates from Switzerland by 3'-UTR comparison. The lower similarity of the $\mathrm{CP}$ sequence from the Brazilian isolates with those from South American, PVYCOAT from Argentina (95.9\% with PVY-OBR and $93.3 \%$ with PVY-NBR) and PVYCAPA from Chile (96.3\% with PVY-OBR and $94.0 \%$ with PVYNBR), is well justified by the high rate of seed potato importation from Canada and Europe (SECEX/DECEX, 1999). This result confirmed that seed potato importation constitutes an easy entrance of new viruses or viral isolates 


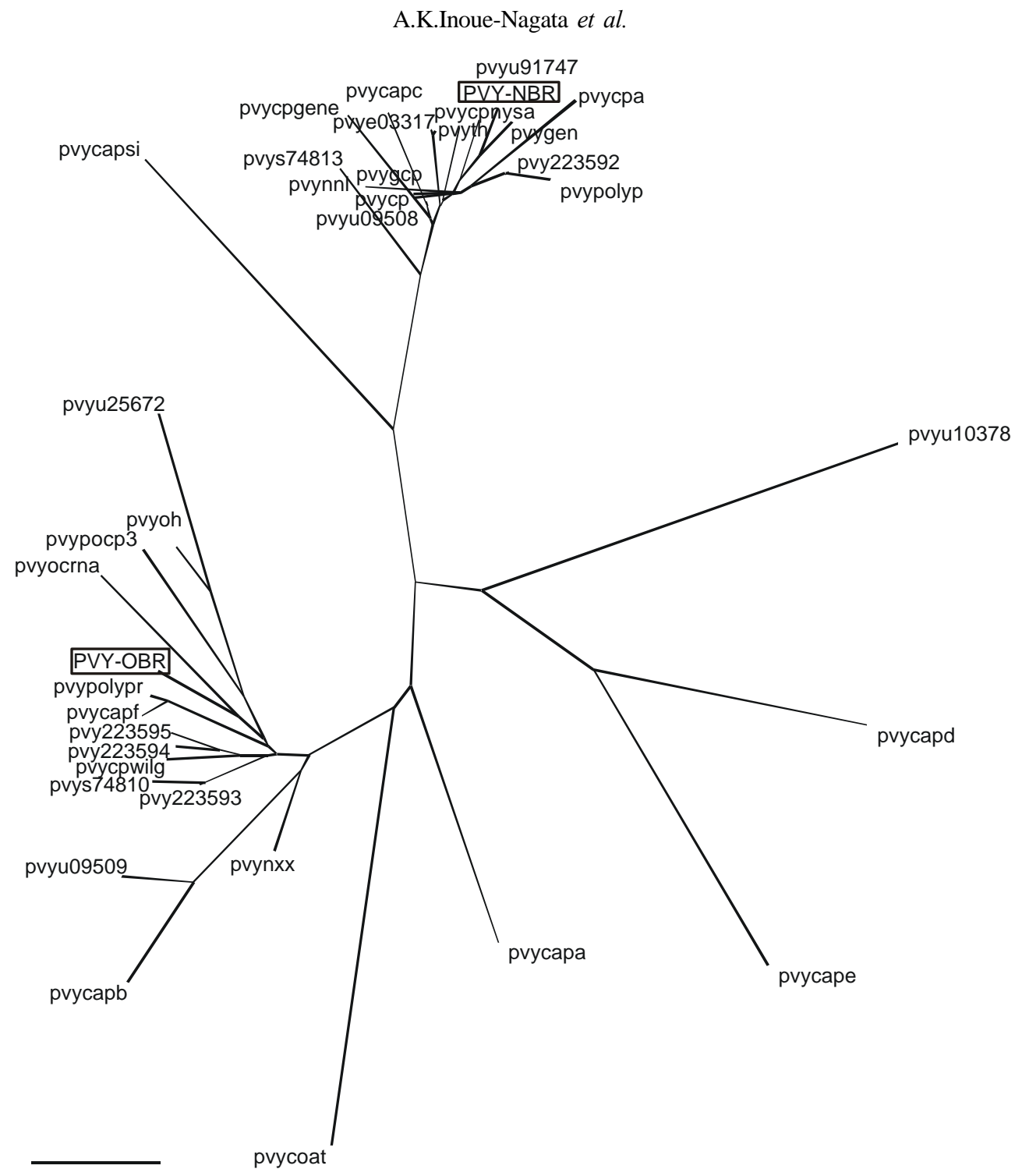

FIG. 2 - Unrooted phylogenetic tree of 37 coat protein amino acid sequences from different PVY accessions (Table 3). The Brazilian isolates, PVY-OBR and PVY-NBR, are boxed. Bar represents 0.01 amino acid substitutions per site.

into the country (Figueira et al., 1998), which may quickly spread throughout potato production areas.

The analysis of the phylogenetic trees from the $\mathrm{CP}$ and 3'-UTR sequence revealed two distinct clusters, one comprising most of the $\mathrm{PVY}^{\mathrm{O}}$ sequences and the other with $\mathrm{PVY}^{\mathrm{N}}$ ones. In the CP analysis, the two clusters showed a good correlation with the biological properties of the isolates, with the exception of PVYNXX and PVYCPWILG, two necrotic isolates grouped in the $\mathrm{PVY}^{\mathrm{O}}$ cluster. This tree separated the potato strain from Russia (PVYCAPSI), the pepper strain (PVYU10378), the tobacco isolates (PVYCAPD, PVYCAPE and PVYCAPA) and the PVY ${ }^{\circ}$ from Argentina (PVYCOAT) from the two clusters. The separation of the isolates from Russia, Argentina and Chile (PVYCAPA) may indicate isolated geographical evolution of these viruses. Pepper and tobacco isolates are still poorly studied, but they formed a separate group suggesting a possible correlation among them. This result confirms the grouping of PVY isolates in $\mathrm{PVY}^{\mathrm{O}}, \mathrm{PVY}^{\mathrm{N}}$ and non-potato isolates according to RFLP analysis of the CP (Blanco-Urgoiti et al., 1996).

Thirty seven PVY sequences were analyzed for the CP alignment, but only 20 were available for the 3'-UTR analysis. The 3'-UTR tree showed a well defined grouping of $\mathrm{PVY}^{\mathrm{O}}$ and $\mathrm{PVY}^{\mathrm{N}}$ and a separate and isolated sequence of PVYNXX, a PVYN isolate from France. Although this isolate was necrotic to $N$. tabacum (Robaglia et al., 1989), it was consistently clustered with the $\mathrm{PVY}^{\mathrm{O}}$ isolates when the CP gene was analyzed (Figure 2). This result confirms the previous alignment of $21 \mathrm{CP}$ sequences, which showed the grouping of PVYNXX in the PVY ${ }^{\circ}$ group (Van der Vlugt et al., 1993). The analysis of the PVYNXX 3'-UTR region showed a mixture of a $\mathrm{PVY}^{\mathrm{O}}$-like 5'-region followed by a highly divergent stretch of nucleotides and a $\mathrm{PVY}^{\mathrm{N}}$-like sequence at its 3' termini (data not shown). The PVYCPWILG 
Analysis of the nucleotide sequence of the coat protein...

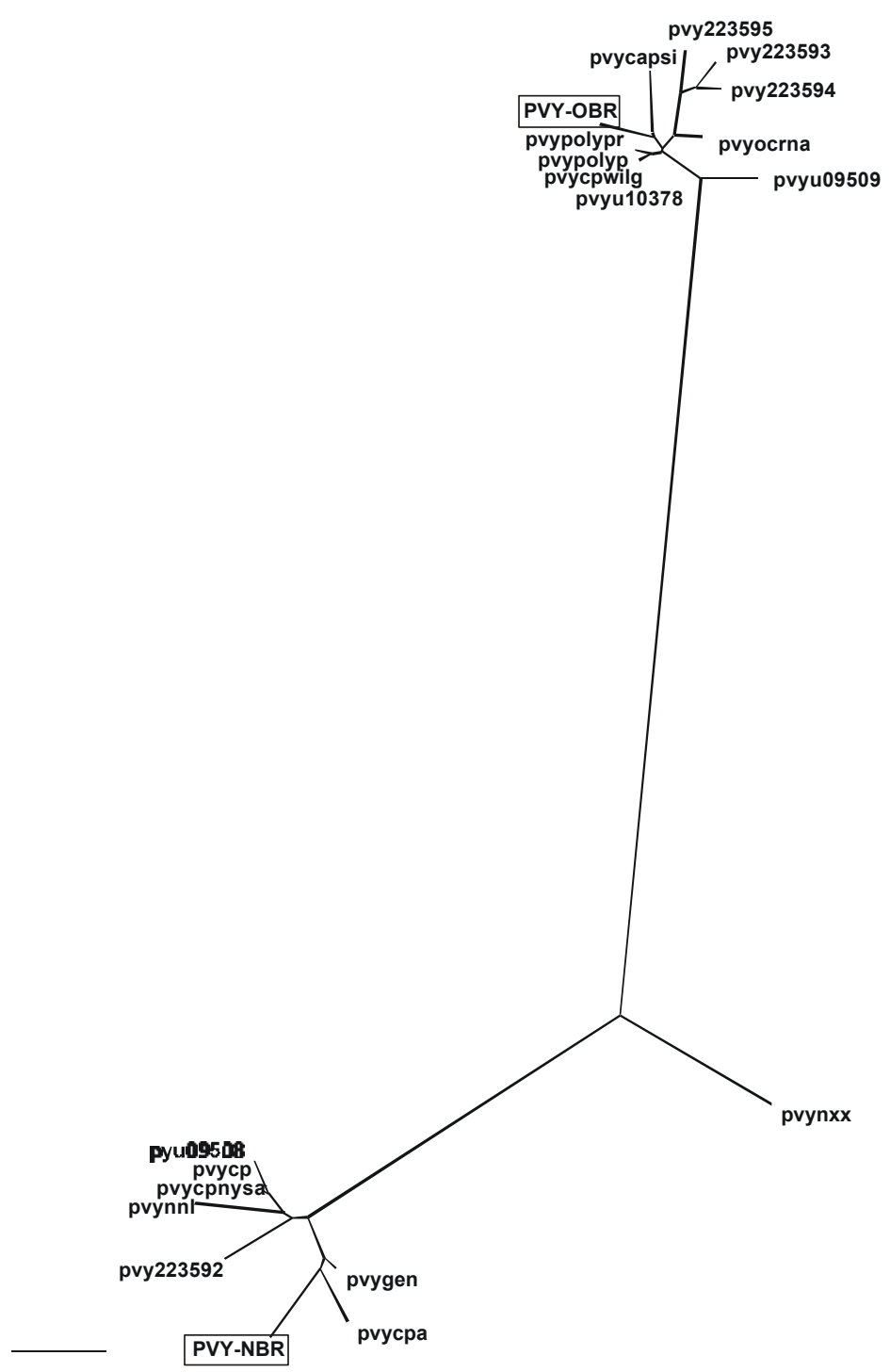

FIG. 3 - Unrooted phylogenetic tree of 20 3'-UTR nucleotide sequences from different Potato virus $Y$ accessions (Table 3). The Brazilian isolates, PVY-OBR and PVY-NBR, are boxed. Bar represents 0.01 nucleotide substitutions per site.

was also a necrotic isolate but which was clustered in both trees with $\mathrm{PVY}^{\mathrm{O}}$-like isolates. The PVYNTN isolates (PVYPOLYP and PVYGCP) were grouped in PVY ${ }^{\mathrm{N}}$ cluster by the CP analysis, but the 3'-UTR of PVYPOLYP was closer to $\mathrm{PVY}{ }^{\mathrm{O}}$. Therefore, the nucleotide sequence of $\mathrm{CP}$ and 3'UTR was not useful to distinguish PVY ${ }^{\mathrm{NTN}}$ from other PVY isolates. PVY ${ }^{\mathrm{NTN}}$ is also indistinguishable from $\mathrm{PVY}^{\mathrm{N}}$ by serology and host response (Weilguny \& Singh, 1998). These results confirm the report that the necrotic reaction determinants in PVY are not localized in the 3' half portion of the genome (Chachulska et al., 1997).

The nucleotide sequence determination of the $\mathrm{CP}$ is postulated as the basis for identification and classification in the Potyvirus genus (Shukla \& Ward, 1988). The comparison of two PVY strains with several PVY isolates confirmed the overall clustering into $\mathrm{PVY}^{\mathrm{O}}$ and $\mathrm{PVY}^{\mathrm{N}}$ groups. However, the existence of many variants with distinct biological responses and nucleotide sequences showed that characterization studies of new isolates must include a description of their biological properties.

\section{ACKNOWLEDGEMENTS}

We thank Dr. René Van der Vlugt and Dr. Tatsuya Nagata for critically reading the manuscript.

\section{LITERATURE CITED}

ALEXANDRE, M.A.V. \& BARRADAS, M.M. Solanum mammosum L. nova hospedeira diferencial para o vírus Y da batata (PVY) e sua estirpe necrótica (PVYN). Fitopatologia Brasileira 7:105-109. 1982.

ATREYA, P.L., ATREYA, C.D. \& PIRONE, T.P. Amino acid substitutions in the coat protein result in loss of insect 
transmissibility of a plant virus. Proceedings National Academy Sciences. USA. 88:7887-7891. 1991.

BECZNER, L., HORVATH, H., ROMHANYI, I. \& FORSTER, H. Studies on the aetiology of tuber necrotic ringspot disease in potato. Potato Research 27:339-351. 1984.

BLANCO-URGOITI, B., SÁNCHEZ, F., DOPAZO, J. \& PONZ, F. A strain-type clustering of potato virus $\mathrm{Y}$ based on the genetic distance between isolates calculated by RFLP analysis of the amplified coat protein gene. Archives of Virology 141:2425-2442. 1996.

BRAVO-ALMONACID, F. \& MENTABERRY, A.N. Nucleotide cDNA sequence coding for the PVYO coat protein. Nucleic Acids Research. 17:4401. 1989.

CHACHULSKA, A.M., CHRZANOWSKA, M., ROBAGLIA, C. \& ZAGÓRSKI, W. Tobacco veinal necrosis determinants are unlikely to be located within the 5' and 3' terminal sequences of the potato virus $\mathrm{Y}$ genome. Archives of Virology 142:765-779. 1997.

DE BOKX, J.A. \& HUTTINGA, H. Potato virus Y. CMI/ AAB. Descriptions of Plant Viruses, no. 242. 1981.

DEVEREUX, J., HAEBERLI, P. \& SMITHIES, O. A comprehensive set of sequence analysis programs for the VAX. Nucleic Acids Research 12:387-395. 1984.

FIGUEIRA, A.R., BARROCAS, E.N., SANTOS, R.C. \& MORAES, F.H.R. Influência da nova estirpe necrótica do vírus $\mathrm{Y}$ da batata na escolha de cultivares de batata plantadas em Minas Gerais. Fitopatologia Brasileira 23: (Suplemento):317. 1998. (Resumo)

HATAYA, T., SANO, T., OHSHIMA, K. \& SHIKATA, E. Polymerase chain reaction-mediated cloning and expression of the coat protein gene of potato virus $\mathrm{Y}$ in Escherichia coli. Virus Genes 4:339-350. 1990.

LE ROMANCER, M., KERLAN, C. \& NEDELLEC, M. Biological characterisation of various geographical isolates of potato virus Y inducing superficial necrosis on potato tubers. Plant Pathology 43:138-144. 1994.

MONTENEGRO, M.J., KITAJIMA, E.W., CAMARGO, L.J.B. \& COSTA, A.S. Comparação eletronomicroscópica dos tecidos de plantas infetadas por diferentes estirpes do vírus Y da batata que ocorrem no estado de São Paulo. Bragantia 27: 17-23. 1968.

OHSHIMA, K., HATAYA, T., SANO, T., INOUE, A.K. \&
SHIKATA, E. Comparison of biological properties, serological characteristics and amino acid sequences of coat protein between potato virus Y ordinary strain and necrotic strain. Annals of the Phytopahological Society of Japan 57:615-622. 1991.

ROBAGLIA, C., DURAND-TARDIF, M., TRONCHET, M., BOUDAZIR, G., ASTIER-MANIFACIER, S. \& CASSE-DELBART, F. Nucleotide sequence of potato virus $\mathrm{Y}$ (N strain) genomic RNA. Journal of General Virology 70:935-947. 1989.

SECEX/DECEX BRASIL. Ministério da Indústria e Comércio. Secretaria de Comércio Exterior. Importações efetivas-dados preliminares. Brasília, 1999. (Listagens saídas de computador).

SHUKLA, D.D. \& WARD, C.W. Amino acid sequence homology of coat proteins as a basis for identification and classification of the potyvirus group. Journal of General Virology 69: 7203-7210. 1988.

SILBERSCHMIDT, K., ROSTOM, E. \& ULSON, C.M. A strain of potato virus $\mathrm{Y}$ inducing local and systemic necrotic spots on leaves of tobacco White Burley. American Potato Journal 31:213-317. 1954.

TENNANT, P.F., GONSALVES, C., LING, K.-S., FITCH, M., MANSHARDT, R., SLIGHTOM, J.L. \& GONSALVES, D. Differential protection against papaya ringspot virus isolates in coat protein gene transgenic papaya and classically cross-protected papaya. Phytopathology 84:1359-1366. 1994.

VAN DER VLUGT, R.A.A., ALLEFS, S., DE HAAN, P.T. $\&$ GOLDBACH, R.W. Nucleotide sequence of the 3'terminal region of the potato virus Y-N RNA. Journal of General Virology 70:229-233. 1989.

VAN DER VLUGT, R.A.A., LEUNISSEN, J. \& GOLDBACH, R. Taxonomic relationships between distinct potato virus $\mathrm{Y}$ isolates based on detailed comparisons of the viral coat proteins and 3'nontranslated regions. Archives of Virology 131:361375. 1993.

WEILGUNY, H. \& SINGH, R.P. Separation of Slovenian isolates of PVYNTN from the North American isolates of PVYN by a 3-primer PCR. Journal of Virological Methods 71:57-68. 1998. 